Volume: 11 Issue: 2 Year: 2014

\title{
Research on preferences for participation in search and rescue activities: "Akut" search and rescue association sample
}

\author{
Burak Gürer ${ }^{1}$ \\ Zühal K1lınç ${ }^{2}$
}

\begin{abstract}
Current study aimed to identify why AKUT Search and Rescue (SAR) Association Members participate in SAR, specify expectations and examine activities in terms of various demographics. 126 AKUT members (103 male, 23 female) participated in the study. Data with .84 reliability coefficient was collected with a survey. Data analysis included frequencies, percentage distribution, t-test and ANOVA. Level of statistical significance was .05. Although results didn't pinpoint distinctive reasons for participating in SAR, prominent elements affecting members were identified as "Existence of trainers in immediate vicinity" (19\%) and "Impact of friends/peer groups" (17.5\%). Results showed that impact of family $(73 \%)$ was not important but age was. It was also found that single individuals inclined towards SAR to a higher extent. Reasons for continuing activities were "Caring for SAR" (50\%) and "Awareness of positive contributions" (48.4\%). Contributing to financial income was found to have no relationship with SAR (90.5\%). No relationship was detected between reasons participating in SAR and demographic characteristics. Expectations from SAR were mostly related to "being a trainer" $(53.2 \%)$. Expectations and age were found to be related. Younger and single members had higher expectations for being trainers in future. Results showed that volunteerism had important implications in current study.
\end{abstract}

Keywords: Search and Rescue; Reasons for Participating in Search and Rescue Activities; Expectations from Search and Rescue Activities

\section{Introduction}

Natural disasters generate need for various materials, create serious damages to the infrastructure, damage communication channels, weaken local management capacity due to stress and loss of important personnel and result in high media pressure based on bilateral and international support to the country affected by the disaster. These are the major characteristics of natural disasters that occur suddenly (Gülkan, Balamir \& Yakut, 2003). Search and rescue is the activity to save the casualties and survivors injured or facing death and cannot manage to rescue

\footnotetext{
${ }^{1}$ Assist. Prof. Dr., Batman University, School of Physical Education and Sport, burakgurer27@gmail.com

${ }^{2}$ Assist. Prof. Dr., Batman University, School of Physical Education and Sport, zuhalkilinc14@gmail.com
} 
Gürer, B., \& Kılınç, Z. (2014). Research on preferences for participation in search and rescue activities: "Akut" search and rescue association sample. International Journal of Human Sciences, 11(2), 754-769. doi: $\underline{10.14687 / \text { ijhs.v11i2.2853 }}$

themselves in an accident or a natural disaster (Gürer, 2012:27). In recent years risk management has been the most discussed topic in nature and adventure fields due to increases of accidents throughout the world. Organizations are taking the smallest detail into account in their operations and policies in order to minimize the possible risks (Wu \& Chang, 2010). Disasters or accidents cannot be completely prevented. This reality brings us in touch with the reality of the need for search and rescue activities (IAMSAR, 2008:11).

Due to our nature, all individuals are motivated to keep on living instead of dying when their lives are in danger (McManners, 2009:11). It is impossible to know in advance when, where and how accidents will take place or how they will develop, how serious or damaging they will be and how many persons will suffer (IAMSAR, 2008:11). Setnicka (1980) stated that many elements are involved in search and rescue.

Search and rescue is a dangerous task since it is impossible to realize the events that may necessitate search and rescue. Search and rescue activities are always undertaken in complex and stressful environments (Gürer, 2012). In this sense, current study is rather important. Search and rescue activities require various skills such as having a sense of direction, looking for directions, mapping, surveying and finding the victim among many others (Calisi et. al., 2009:1205). There are internationally accepted fundamental values related to search and rescue which is a sensitive and equally important activity. Some character traits exist that the personnel participating in search and rescue operations should maintain. These are;

- Patience and endurance,

- Devotion to the task during rescue (commitment),

- Empathy and communication skills,

- Frankness and feelings of synergy and unity,

- Experience (IAMSAR, 2008:55)

Search and rescue becomes more important with the passage of time since survival is substantially reduced as time passes. Natural disasters and accidents that have also increased in our country prove the importance and the need for search and rescue operations. In this context, personnel who take part in search and rescue operations are highly important. The current study investigated the reasons why individuals participating in search and rescue operations preferred to take part in search and rescue. With the advance of technology, new generation systems and 
Gürer, B., \& Kllınç, Z. (2014). Research on preferences for participation in search and rescue activities: "Akut" search and rescue association sample. International Journal of Human Sciences, 11(2), 754-769. doi: $\underline{10.14687 / \text { ijhs.v11i2.2853 }}$

robots are being designed to reach individuals in a faster and more efficient manner and to provide speedy intervention and rescue (Saeedi \& Sorensen, 2009). Although search and rescue activities generally centered on the physical prowess and competence of individuals in the past, today's advance information and communication technologies have enabled search and rescue operations to use techniques encapsulating inter forms of different sciences and are dominantly based on computer technologies. Use of such techniques in search and rescue activities has prevented death and disabilities resulting from accidents and is useful in avoiding accidents altogether (Adakale, 2011). Search and rescue teams should be available for regular and continuous interventions at all times. They should be ready to work against all challenges. Each team should be able to succeed in daytime and nighttime rescue and manage to undertake rescue operations under all sorts of compelling conditions. Existence of urban search and rescue teams in each region (USAR) will expedite interventions (Collins, 2010:51).

Sample of the current study consisted of the members of AKUT Search and Rescue Association. The sample included the members who worked in the association actively for a minimum of two years. Many of the participants completed advance training and took important roles in the provinces they lived in. Current study aimed to identify the reasons why search and rescue personnel were interested in these activities and determine their expectations.

\section{Method}

\section{Universe and Sample}

The universe of the study was composed of the members of AKUT Search and Rescue Association who participated in search and rescue operations for many disasters in the country. AKUT is an organization established in 32 provinces of Turkey. Sample of the study was composed of the members of AKUT who participated in association activities actively for at least two years and who could be trainers based on their training. A total of 126 AKUT members participated in the study. 103 of the participants were males whereas 23 were females. 13 of the survey forms failed to be filled completely of correctly were eliminated from data analysis. During data collection, 14 forms filled by non-AKUT members were also eliminated. 
Gürer, B., \& Kılınç, Z. (2014). Research on preferences for participation in search and rescue activities: "Akut" search and rescue association sample. International Journal of Human Sciences, 11(2), 754-769. doi: $10.14687 /$ ijhs.v11i2.2853

\section{Data Collection Tool}

A survey with a total of items was used to assess the reasons why individuals participated in search and rescue operations and their expectations. The survey has been previously used in various other studies (Ölçücü et. al., 2012; Yıldırım, 2007; Sunay \& Saracaloğlu, 2003; Bayraktar \& Sunay, 2004; Şimşek, 2005). The survey was reorganized in line with the purpose of the current study and implemented on the study group as the data collection tool. Internal consistency reliability coefficient of the survey was calculated as 0.84 . The survey is composed of three sections.

1- Participants' views regarding the reasons of joining search and rescue activities

2- Participants' views regarding their continuous interest in search and rescue activities

3- Participants' views regarding their expectations from search and rescue activities

The intervals in the 5 -point Likert scale were determined with the help of $4 / 5=0.80$ formula. Accordingly, the scoring was as follows: $1.00-1.80$ (None), $1.81-2.60$ (Little), $2.61-3.40$ (Medium), $3.41-4.20$ (A lot), $4.21-5.00$ (Very high).

\section{Data Collection}

Data were collected by the researcher during the training held by AKUT Search and Rescue Association in Antalya Olimpos between 7-10 Novemeber 2013. The survey was also sent by email to AKUT units. The majority of the surveys were collected by the researcher during the training in Antalya.

\section{Data Analysis}

Statistical analyses were undertaken with SPSS for Windows 16.0 package program for frequencies, percentages and arithmetic means. While identifying the differences between scores obtained in the study, Independent Samples t-test was used for between-groups comparisons in cases where there were two groups and One Way Variance Analysis (ANOVA) was used for more than two groups in comparing quantitative data. "Tukey" test was carried out to determine the groups which generated the differences. Results were examined according to $\mathrm{p}<0,05$ significance level. 
Gürer, B., \& Kılınç, Z. (2014). Research on preferences for participation in search and rescue activities: "Akut" search and rescue association sample. International Journal of Human Sciences, 11(2), 754-769. doi: $\underline{10.14687 / \text { ijhs.v11i2.2853 }}$

\section{Results}

Table 1: Demographic Characteristics of Participants

Number of Participants $\quad \%$

\section{GENDER}

Male

Female

\section{AGE RANGE}

MARITAL STATUS

Married

\section{LEVEL OF EDUCATION}

Primary

High School

University

Postgraduate

TOTAL
100

A total of 126 individuals participated in the study. $81.7 \%$ of the participants were male whereas $18.3 \%$ of the participants were females. The largest age range in the study was found to be 18-25 with $25.4 \%$. Single participants constituted $67.5 \%$ of the study group. One of the most noticeable percentages was the percentage of university graduate participants with $67.5 \%$. 
Gürer, B., \& Kılınç, Z. (2014). Research on preferences for participation in search and rescue activities: "Akut" search and rescue association sample. International Journal of Human Sciences, 11(2), 754-769. doi: 10.14687/ijhs.v11i2.2853

Table 2: Distribution of views regarding the reasons of participating in search and rescue activities

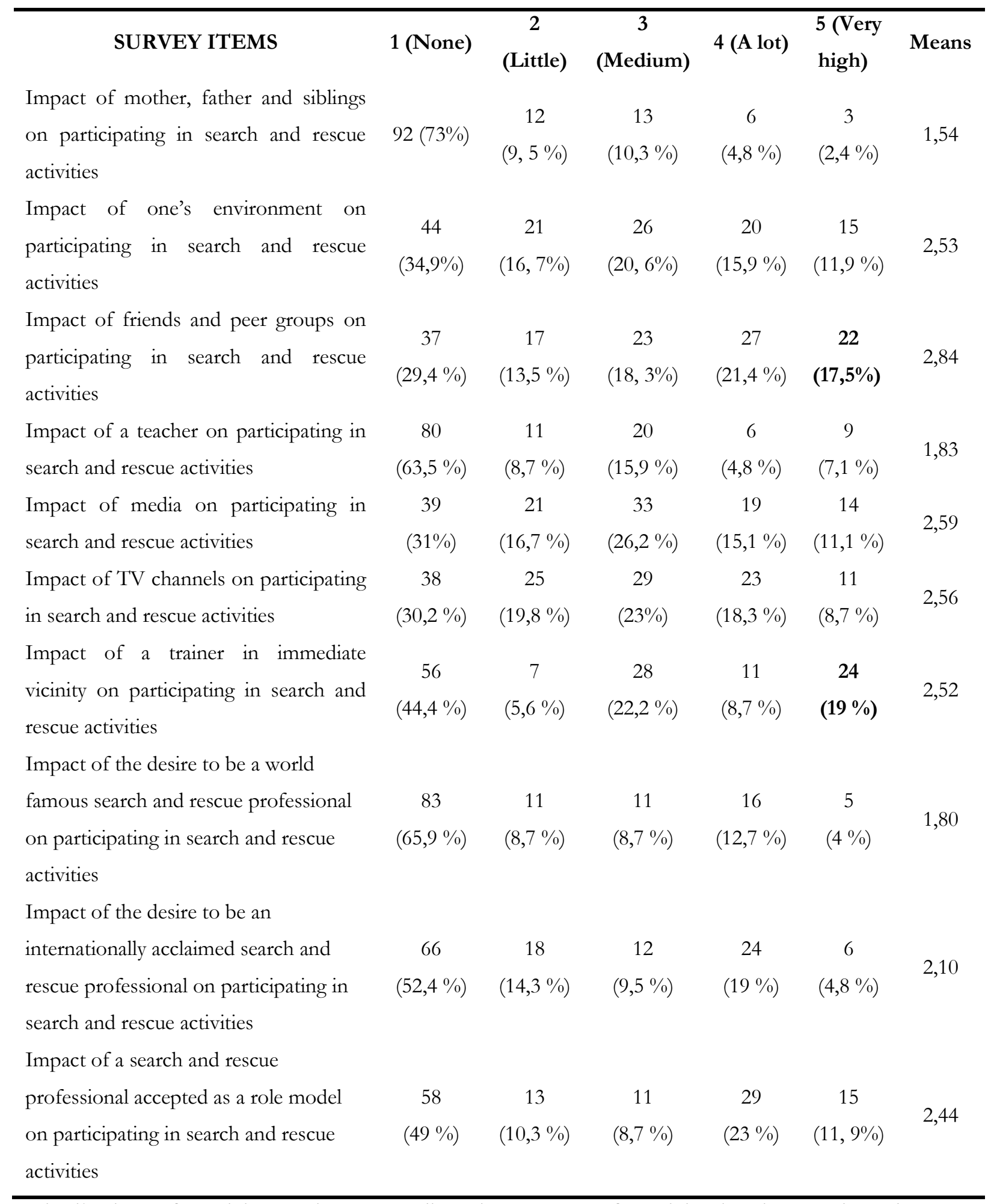

Distribution of participant views regarding the reasons of participating in search and rescue activities shows that "Impact of a trainer in immediate vicinity" was the item selected by the 
Gürer, B., \& Kılınç, Z. (2014). Research on preferences for participation in search and rescue activities: "Akut" search and rescue association sample. International Journal of Human Sciences, 11(2), 754-769. doi: $\underline{10.14687 / \text { ijhs.v11i2.2853 }}$

participants the most $(19 \%)$ as the reason for participating in search and rescue activities. Another noticeable reason in the cluster was found to be "Impact of friends and peer groups" (17.5\%). Examination of Table 2 shows that there is not a highly definitive reason for participating in search and rescue activities. Other options were generally selected at the medium level by the participants. It was also found that "Impact of mother, father and siblings" (73\%) and "Desire to be world famous search and rescue professional" (65.9\%) were not effective in deciding to participate in search and rescue activities. Examination of the distribution shows that there is not a highly definitive item for participating in search and rescue activities. The general means of these two items were calculated to be 1.54 and 1.80 which coincide with "none" option.

Table 3: Analysis of reasons of participating in search and rescue activities according to some demographic characteristics

\begin{tabular}{|c|c|c|c|c|c|}
\hline Age (I) & Age (J) & Means & Average Difference & Sig. & $\mathbf{P}(\mathbf{P}<0,05)$ \\
\hline \multirow[t]{6}{*}{$18-25$} & & 2,69 & & & \multirow{6}{*}{$\underline{0,012}$} \\
\hline & $26-30$ & 2,16 & ,53497 & 0,175 & \\
\hline & $31-35$ & 2,30 & ,39021 & 0,401 & \\
\hline & $36-40$ & 2,10 & ,59687 & 0,073 & \\
\hline & $41-45$ & 1,81 & ,88438 & 0,067 & \\
\hline & 45-üstü & 1,90 & ,79688 & 0,059 & \\
\hline Level of & Level of & Means & Average Difference & Sig. & $\mathrm{P}(\mathrm{P}<0,05)$ \\
\hline \multirow[t]{4}{*}{$\begin{array}{l}\text { Education (I) } \\
\text { Primary }\end{array}$} & Education (J) & 1,66 & & & \multirow{4}{*}{0,300} \\
\hline & High School & 2,30 &,- 63788 & 0,601 & \\
\hline & University & 2,33 &,- 67216 & 0,520 & \\
\hline & Postgraduate & 2,01 &,- 34583 & 0,912 & \\
\hline Gender & \multicolumn{2}{|l|}{$\mathbf{N}$} & Standard Deviation & $\begin{array}{c}\text { Average } \\
\text { Score }\end{array}$ & $P(P<0,05)$ \\
\hline Male & 103 & & 0,84 & 2,31 & \multirow{2}{*}{0,223} \\
\hline Female & 23 & & 0,80 & 2,08 & \\
\hline Marital Status & \multicolumn{2}{|l|}{$\mathbf{N}$} & Standard Deviation & $\begin{array}{c}\text { Average } \\
\text { Score }\end{array}$ & $P(P<0,05)$ \\
\hline Married & 41 & & 0,81 & 1,96 & \multirow{2}{*}{$\underline{0,004} *$} \\
\hline Single & 85 & & 0,80 & 2,42 & \\
\hline
\end{tabular}


Gürer, B., \& Kıllnç, Z. (2014). Research on preferences for participation in search and rescue activities: "Akut" search and rescue association sample. International Journal of Human Sciences, 11(2), 754-769. doi: 10.14687/ijhs.v11i2.2853

A significant difference was found between age and reasons for participating in search and rescue activities. According to the results of analysis, increase in age coincides with decrease in having reasons for participation in search and rescue activities. Value of P was calculated as 0.012. Another meaningful difference was found for marital status $(0,004)$.

Table 4: Distribution of views regarding the reasons for continuing search and rescue activities

\begin{tabular}{|c|c|c|c|c|c|c|}
\hline SURVEY ITEMS & $\begin{array}{c}1 \\
\text { (None) }\end{array}$ & 2 (Little) & $\begin{array}{c}3 \\
\text { (Medium) }\end{array}$ & $\begin{array}{l}4(\mathrm{~A} \\
\text { lot })\end{array}$ & $\begin{array}{l}5 \text { (Very } \\
\text { high) }\end{array}$ & Means \\
\hline Increasing financial income & $\begin{array}{c}114 \\
(90,5 \%)\end{array}$ & $\begin{array}{c}4 \\
(3,2 \%)\end{array}$ & $\begin{array}{c}5 \\
(4 \%)\end{array}$ & $\begin{array}{c}0 \\
(0 \%)\end{array}$ & $\begin{array}{c}3 \\
(2,4 \%)\end{array}$ & 1,21 \\
\hline Caring for search and rescue & $\begin{array}{c}2 \\
(1,6 \%)\end{array}$ & $\begin{array}{c}1 \\
(0,8 \%)\end{array}$ & $\begin{array}{c}8 \\
(6,3 \%)\end{array}$ & $\begin{array}{c}52 \\
(41,3 \%)\end{array}$ & $\begin{array}{c}63 \\
(50 \%)\end{array}$ & 4,37 \\
\hline $\begin{array}{l}\text { Being aware of the positive } \\
\text { contributions of search and } \\
\text { rescue activities }\end{array}$ & $\begin{array}{c}6 \\
(4,8 \%)\end{array}$ & $\begin{array}{c}4 \\
(3,2 \%)\end{array}$ & $\begin{array}{c}15 \\
(11,9 \%)\end{array}$ & $\begin{array}{c}40 \\
(31,7 \%)\end{array}$ & $\begin{array}{c}61 \\
(48,4 \%)\end{array}$ & 4,16 \\
\hline $\begin{array}{l}\text { Making use of free time } \\
\text { positively with the help of } \\
\text { search and rescue activities }\end{array}$ & $\begin{array}{c}20 \\
(15,9 \%)\end{array}$ & $\begin{array}{c}8 \\
(6,3 \%)\end{array}$ & $\begin{array}{c}29 \\
(23 \%)\end{array}$ & $\begin{array}{c}30 \\
(23,8 \%)\end{array}$ & $\begin{array}{c}39 \\
(31 \%)\end{array}$ & 3,38 \\
\hline $\begin{array}{l}\text { Getting healthier with the help } \\
\text { of search and rescue activities }\end{array}$ & $\begin{array}{c}25 \\
(19,8 \%)\end{array}$ & $\begin{array}{c}23 \\
(18,3 \%)\end{array}$ & $\begin{array}{c}35 \\
(27,8 \%)\end{array}$ & $\begin{array}{c}25 \\
(19,8 \%)\end{array}$ & $\begin{array}{c}18 \\
(14,3 \%)\end{array}$ & 2,90 \\
\hline $\begin{array}{l}\text { Being recognized and } \\
\text { respected as a search and } \\
\text { rescue personnel by friends }\end{array}$ & $\begin{array}{c}50 \\
(39,7 \%)\end{array}$ & $\begin{array}{c}30 \\
(23,8 \%)\end{array}$ & $\begin{array}{c}23 \\
(18,3 \%)\end{array}$ & $\begin{array}{c}11 \\
(8,7 \%)\end{array}$ & $\begin{array}{c}12 \\
(9,5 \%)\end{array}$ & 2,25 \\
\hline $\begin{array}{l}\text { Enjoying the feelings of } \\
\text { success }\end{array}$ & $\begin{array}{c}17 \\
(13,5 \%)\end{array}$ & $\begin{array}{c}19 \\
(15,1 \%)\end{array}$ & $\begin{array}{c}37 \\
(29,4 \%)\end{array}$ & $\begin{array}{c}34 \\
(27 \%)\end{array}$ & $\begin{array}{c}19 \\
(15,1 \%)\end{array}$ & 3,15 \\
\hline Visiting new countries & $\begin{array}{c}74 \\
(58,7 \%)\end{array}$ & $\begin{array}{c}17 \\
(13,5 \%)\end{array}$ & $\begin{array}{c}11 \\
(8,7 \%)\end{array}$ & $\begin{array}{c}10 \\
(7,9 \%)\end{array}$ & $\begin{array}{c}14 \\
(11,1 \%)\end{array}$ & 1,99 \\
\hline $\begin{array}{l}\text { Finding the true happiness in } \\
\text { search and rescue activities }\end{array}$ & $\begin{array}{c}25 \\
(19,8 \%)\end{array}$ & $\begin{array}{c}28 \\
(22,2 \%)\end{array}$ & $\begin{array}{c}26 \\
(20,6 \%)\end{array}$ & $\begin{array}{c}19 \\
(15,1 \%)\end{array}$ & $\begin{array}{c}28 \\
(22,2 \%)\end{array}$ & 2,98 \\
\hline
\end{tabular}

When the distribution of participant views regarding their continuous interest in search and rescue activities was examined, it was found that "Caring for search and rescue" (50\%) was highly effective in their continuous interest in these activities. "Being aware of the positive contributions 
Gürer, B., \& Kılınç, Z. (2014). Research on preferences for participation in search and rescue activities: "Akut" search and rescue association sample. International Journal of Human Sciences, 11(2), 754-769. doi: 10.14687/ijhs.v11i2.2853

of search and rescue activities" (48.4\%) was found to be the most selected option in the cluster. The answers provided by the participants to these options coincide with the option "a lot".

90.5\% of the participants emphasized that increasing financial income was not important in their interest to participate in these activities. "Visiting new countries" (58.7\%) and "Being recognized and respected as a search and rescue personnel by friends" (39.7\%) were not found to be effective as reasons for continuing interest in search and rescue operations. General means of these three survey items were calculated $(1,99 ; 1,21$ and 2,25$)$ and the means were found to coincide with "little" option.

Table 5: Analysis of reasons for continuing search and rescue activities according to some demographic characteristics

\begin{tabular}{|c|c|c|c|c|c|}
\hline Age (I) & Age (J) & Means & $\begin{array}{c}\text { Average } \\
\text { Difference }\end{array}$ & Sig. & $\begin{array}{c}\mathrm{P} \\
(\mathrm{P}<0,05)\end{array}$ \\
\hline \multirow[t]{6}{*}{$18-25$} & & 3,03 & & & \multirow{6}{*}{0,617} \\
\hline & $26-30$ & 3,06 &,- 03406 & 1,000 & \\
\hline & $31-35$ & 2,95 & ,07917 & 0,997 & \\
\hline & $36-40$ & 2,83 & , 19676 & 0,884 & \\
\hline & $41-45$ & 2,83 & ,20139 & 0,973 & \\
\hline & 45-üstü & 2,70 & ,32765 & 0,724 & \\
\hline \multirow{5}{*}{$\begin{array}{l}\text { Level of } \\
\text { Education (I) } \\
\text { Primary }\end{array}$} & \multirow[t]{2}{*}{$\begin{array}{l}\text { Level of Education } \\
\text { (J) }\end{array}$} & Means & $\begin{array}{l}\text { Average } \\
\text { Difference }\end{array}$ & Sig. & \multirow[t]{2}{*}{$\begin{array}{l}P \\
(P<0,05)\end{array}$} \\
\hline & & 2,88 & & & \\
\hline & \multirow{2}{*}{$\begin{array}{l}\text { High School } \\
\text { University }\end{array}$} & 2,99 &,- 10606 & 0,994 & \multirow{3}{*}{0,273} \\
\hline & & 2,98 &,- 09935 & 0,994 & \\
\hline & Postgraduate & 2,63 & ,25000 & 0,931 & \\
\hline Gender & \multicolumn{2}{|l|}{$\mathbf{N}$} & $\begin{array}{l}\text { Standard } \\
\text { Deviation }\end{array}$ & $\begin{array}{l}\text { Average } \\
\text { Score }\end{array}$ & $\begin{array}{c}P \\
(P<0,05)\end{array}$ \\
\hline Male & \multicolumn{2}{|l|}{103} & 0,674 & 2,96 & \multirow{2}{*}{0,333} \\
\hline Female & 23 & & 0,607 & 2,82 & \\
\hline Marital Status & $\mathbf{N}$ & & $\begin{array}{l}\text { Standard } \\
\text { Deviation }\end{array}$ & $\begin{array}{l}\text { Average } \\
\text { Score }\end{array}$ & $\begin{array}{c}P \\
(P<0,05)\end{array}$ \\
\hline Married & 41 & & 0,71 & 2,91 & \multirow{2}{*}{0,755} \\
\hline Single & 85 & & 0,63 & 2,95 & \\
\hline
\end{tabular}


Gürer, B., \& Kılınç, Z. (2014). Research on preferences for participation in search and rescue activities: "Akut" search and rescue association sample. International Journal of Human Sciences, 11(2), 754-769. doi: 10.14687/ijhs.v11i2.2853

Result of analysis found no significant differences between demographic characteristics and reasons for continuing search and rescue activities $(\mathrm{P}>0.05)$

Table 6: Distribution of participant views regarding their expectations from search and rescue activities

\begin{tabular}{|c|c|c|c|c|c|c|}
\hline SURVEY ITEMS & $\begin{array}{c}1 \\
\text { (None) }\end{array}$ & $\begin{array}{c}2 \\
(\text { Little) }\end{array}$ & $\begin{array}{c}3 \\
\text { (Medium) }\end{array}$ & $\begin{array}{l}4(\mathrm{~A} \\
\text { lot) }\end{array}$ & $\begin{array}{l}5 \text { (Very } \\
\text { high) }\end{array}$ & Means \\
\hline $\begin{array}{l}\text { Being healthy and maintaining } \\
\text { health }\end{array}$ & $\begin{array}{c}17 \\
(13,5 \%)\end{array}$ & $\begin{array}{c}20 \\
(15,9 \%)\end{array}$ & $\begin{array}{c}27 \\
(21,4 \%)\end{array}$ & $\begin{array}{c}38 \\
(30,2 \%)\end{array}$ & $\begin{array}{c}24 \\
(19 \%)\end{array}$ & 3,25 \\
\hline Having a good physical appearance & $\begin{array}{c}37 \\
(29,4 \%)\end{array}$ & $\begin{array}{c}20 \\
(15,9 \%)\end{array}$ & $\begin{array}{c}44 \\
(34,9 \%)\end{array}$ & $\begin{array}{c}12 \\
(9,5 \%)\end{array}$ & $\begin{array}{c}13 \\
(10,3 \%)\end{array}$ & 2,55 \\
\hline $\begin{array}{l}\text { Having relationships with others as } \\
\text { a popular individual undertaking } \\
\text { search and rescue activities }\end{array}$ & $\begin{array}{c}58 \\
(46 \%)\end{array}$ & $\begin{array}{c}41 \\
(32,5 \%)\end{array}$ & $\begin{array}{c}16 \\
(12,7 \%)\end{array}$ & $\begin{array}{c}7 \\
(5,6 \%)\end{array}$ & $\begin{array}{c}4 \\
(3,2 \%)\end{array}$ & 1,87 \\
\hline $\begin{array}{l}\text { Having the opportunity to receive } \\
\text { training on search and rescue at } \\
\text { university level in the future }\end{array}$ & $\begin{array}{c}48 \\
(38,1 \%)\end{array}$ & $\begin{array}{c}18 \\
(14,3 \%)\end{array}$ & $\begin{array}{c}26 \\
(20,6 \%)\end{array}$ & $\begin{array}{c}24 \\
(19 \%)\end{array}$ & $\begin{array}{c}10 \\
(7,9 \%)\end{array}$ & 2,44 \\
\hline $\begin{array}{l}\text { Obtaining scholarships from } \\
\text { universities abroad with the help of } \\
\text { search and rescue activities }\end{array}$ & $\begin{array}{c}88 \\
(69,8 \%)\end{array}$ & $\begin{array}{c}11 \\
(8,7 \%)\end{array}$ & $\begin{array}{c}14 \\
(11,1 \%)\end{array}$ & $\begin{array}{c}7 \\
(5,6 \%)\end{array}$ & $\begin{array}{c}6 \\
(4,8 \%)\end{array}$ & 1,67 \\
\hline Being a trainer & $\begin{array}{c}18 \\
(14,3 \%)\end{array}$ & $\begin{array}{c}8 \\
(6,3 \%)\end{array}$ & $\begin{array}{c}37 \\
(29,4 \%)\end{array}$ & $\begin{array}{c}32 \\
(25,4 \%)\end{array}$ & $\begin{array}{c}31 \\
(24,6 \%)\end{array}$ & 3,40 \\
\hline $\begin{array}{l}\text { Being an instructor in the field of } \\
\text { search and rescue }\end{array}$ & $\begin{array}{c}12 \\
(9,5 \%)\end{array}$ & $\begin{array}{c}11 \\
(8,7 \%)\end{array}$ & $\begin{array}{c}31 \\
(24,6 \%)\end{array}$ & $\begin{array}{c}36 \\
(28,6 \%)\end{array}$ & $\begin{array}{c}36 \\
(28,6 \%)\end{array}$ & 3,58 \\
\hline $\begin{array}{l}\text { Having a financially comfortable } \\
\text { life }\end{array}$ & $\begin{array}{c}96 \\
(76,2 \%)\end{array}$ & $\begin{array}{c}12 \\
(9,5 \%)\end{array}$ & $\begin{array}{c}12 \\
(9,5 \%)\end{array}$ & $\begin{array}{c}2 \\
(1,6 \%)\end{array}$ & $\begin{array}{c}4 \\
(3,2 \%)\end{array}$ & 1,46 \\
\hline $\begin{array}{l}\text { Being an international search and } \\
\text { rescue professional }\end{array}$ & $\begin{array}{c}30 \\
(23,8 \%)\end{array}$ & $\begin{array}{c}24 \\
(19 \%)\end{array}$ & $\begin{array}{c}18 \\
(\% 14,3)\end{array}$ & $\begin{array}{c}22 \\
(17,5 \%)\end{array}$ & $\begin{array}{c}32 \\
(25,4 \%)\end{array}$ & 3,02 \\
\hline $\begin{array}{l}\text { Being a famous search and rescue } \\
\text { professional known by everyone }\end{array}$ & $\begin{array}{c}56 \\
(44,4 \%)\end{array}$ & $\begin{array}{c}30 \\
(23,8 \%)\end{array}$ & $\begin{array}{c}18 \\
(14,3 \%)\end{array}$ & $\begin{array}{c}11 \\
(8,7 \%)\end{array}$ & $\begin{array}{c}11 \\
(8,7 \%)\end{array}$ & 2,13 \\
\hline
\end{tabular}

In terms of expectations from search and rescue, participants emphasized the items "Being healthy and maintaining health" (19\%), "Being a trainer" (24,6\%); "Being an instructor in the field of search and rescue" ( $28,6 \%)$ and "Being an international search and rescue professional" 
Gürer, B., \& Kıllnç, Z. (2014). Research on preferences for participation in search and rescue activities: "Akut" search and rescue association sample. International Journal of Human Sciences, 11(2), 754-769. doi: 10.14687/ijhs.v11i2.2853

$(25,4 \%)$. Means of the answers provided by the participants for these items $(3,25 ; 3,40 ; 3,58 ; 3,02)$ coincide with option "medium".

$76.2 \%$ of the participants emphasized that having a financially comfortable life was not an important expectation for them. Other items that were not considered to be important included "Receiving a scholarship" (69,8\%), "Having relationships with others as a popular individual undertaking search and rescue activities" (46\%) and "Being a famous search and rescue professional known by everyone "(44,4\%). Means of these items were calculated and it was seen that the means coincided with "none" option.

Table 7: Analysis of expectations from search and rescue activities according to some demographic characteristics

\begin{tabular}{|c|c|c|c|c|c|}
\hline Age (I) & Age (J) & Means & $\begin{array}{l}\text { Average } \\
\text { Difference }\end{array}$ & Sig. & $P(P<0,05)$ \\
\hline \multirow[t]{6}{*}{$18-25$} & & 2,81 & & & \\
\hline & $26-30$ & 2,72 & ,09078 & 0,999 & \multirow{5}{*}{$\underline{0,009} *$} \\
\hline & $31-35$ & 2,63 & ,18269 & 0,946 & \\
\hline & $36-40$ & 2,26 &, 55685 & 0,109 & \\
\hline & $41-45$ & 1,82 & ,99435* & 0,024 & \\
\hline & 45-üstü & 2,28 & ,53754 & 0,387 & \\
\hline $\begin{array}{l}\text { Level of } \\
\text { Education (I) }\end{array}$ & $\begin{array}{l}\text { Level of } \\
\text { Education }(J)\end{array}$ & Means & $\begin{array}{l}\text { Average } \\
\text { Difference }\end{array}$ & Sig. & $P(P<0,05)$ \\
\hline \multirow[t]{4}{*}{ Primary } & & 1,96 & & & \\
\hline & High School & 2,63 &,- 66515 & 0,564 & \multirow{3}{*}{0,583} \\
\hline & University & 2,55 &,- 59167 & 0,620 & \\
\hline & Postgraduate & 2,44 &,- 47708 & 0,798 & \\
\hline Gender & $\mathbf{N}$ & & $\begin{array}{l}\text { Standard } \\
\text { Deviation }\end{array}$ & $\begin{array}{l}\text { Average } \\
\text { Score }\end{array}$ & $P(P<0,05)$ \\
\hline Male & \multirow{3}{*}{$\begin{array}{l}103 \\
23\end{array}$} & & 0,808 & 2,60 & \multirow{2}{*}{0,085} \\
\hline Female & & & 0,872 & 2,27 & \\
\hline Marital Status & & & $\begin{array}{l}\text { Standard } \\
\text { Deviation }\end{array}$ & $\begin{array}{l}\text { Average } \\
\text { Score }\end{array}$ & $P(P<0,05)$ \\
\hline Married & 41 & & 0,800 & 2,33 & \multirow{2}{*}{$\underline{0,049} *$} \\
\hline Single & 85 & & 0,824 & 2,64 & \\
\hline
\end{tabular}


Gürer, B., \& Kllınç, Z. (2014). Research on preferences for participation in search and rescue activities: "Akut" search and rescue association sample. International Journal of Human Sciences, 11(2), 754-769. doi: $\underline{10.14687 / \text { ijhs.v11i2.2853 }}$

Results show a meaningful difference between age and expectations from search and rescue activities. According to the results of analysis, level of significance was found to be 0,024 for 18 25 and 41-45 age ranges. Based on the results, it can be argued that younger individuals have higher expectations. Another finding which was found regarding the marital status shows that compared to married individuals, singles had more expectations from search and rescue activities $(0,049)$.

\section{Discussion}

Current study aimed to identify definitive results regarding the reasons for participating in search and rescue activities and the expectations underlining these reasons. It is believed that the reasons for participating search and rescue activities are important to provide effective and productive operations. In this context, the current study aims to shed some light for the future. Administrators and leaders are decision makers in search and rescue activities. Both of these management levels are crucial for successful search and rescue management. Qualified team members can be the leader or the administrator for future tasks especially in small teams (Daughenbaugh, 2002). Study results display a general distribution about the reasons for participating search and rescue activities. Table 2 does not provide a highly definitive factor in terms of participating in search and rescue activities. Two factors seem prominent in this general distribution. "Existence of a trainer in the immediate vicinity" (19\%) and "The impact of friends or peer groups" $(17.5 \%)$ were found to be the most prominent factors that were effective in participating in search and rescue activities. It was found in the study that the impact of the family was very little. $73 \%$ of the participants stated that their families did not have an impact on their decisions in participating in these activities. "Desire to be famous" (65.9\%) was not found to be an important factor as well. Findings and results of the study also have theoretical implications as well. Based on the results, it is possible to claim that family plays no role in starting search and rescue activities; however friends and trainers are more effective. The reason for starting these activities can be associated with the principle of volunteerism. In their study, Gürer, Adiloğulları and Caymaz (2012:296) found that commitment levels of AKUT volunteers did not change based on demographic variables and concluded that it was due to commitment to volunteerism principles. 
Gürer, B., \& Kılınç, Z. (2014). Research on preferences for participation in search and rescue activities: "Akut" search and rescue association sample. International Journal of Human Sciences, 11(2), 754-769. doi: $\underline{10.14687 / \text { ijhs.v11i2.2853 }}$

It was found that age and starting search and rescue activities were related. With the increase in age, preferences to start these activities decrease. It was seen that younger individuals are more interested in search and rescue (42,1\%). Examination of Table 1 and Table 3 shows that younger ages prefer these activities to a higher extent. In this context, it can be claimed that young persons are more willing to participate in search and rescue activities. The fact that individuals under 36 prefer to participate in search and rescue operations can be explained with their marital status. In this sense, marital status is an important factor in participating in these activities $(\mathrm{p}<$ 0.05). Results of the current study show that single individuals have a higher rate of participating in these activities $(67,5 \%$ ). It can also be claimed that single individuals participate in activities that require voluntary participation. Following different approach, this situation can be explained with risk taking behavior. Gürer (2012) emphasized the importance of risk taking in search and rescue activities and concluded that risk taking is a crucial competence in search and rescue personnel.

Reasons for participating in search and rescue activities have many implications. 50\% of the participants stated that they were interested in these activities because they cared for and liked search and rescue. This result can also be associated with volunteerism. Participants also thought that search and rescue activities had positive contributions (48.4\%). It is a necessity for search and rescue operations to have their members in good physical condition since they should be always ready to provide regular and continuous intervention (Collins, 2010:51). In a similar vein, Gürer (2012) also found that being in a good physical condition was an important criterion in search and rescue activities. Caymaz, Erenel and Gürer (2013) remarked that emotional commitment and attachment to group were effective on voluntary work performance. In this sense, commitment and volunteerism are effective in participating in search and rescue activities. In terms of volunteerism, these findings also support the findings of the current study. Financial gain does not affect the reasons for participating in search and rescue activities (90,5\%). Results also show that traveling is not effective as a reason for participating in these activities $(58,7 \%)$. Based on all these results, it can be seen that participating in search and rescue activities are related to caring and volunteerism. In their study, Gürer, Adiloğulları and Caymaz, (2012:296) found that emotional commitment levels of AKUT members were very good. 
Gürer, B., \& Kılınç, Z. (2014). Research on preferences for participation in search and rescue activities: "Akut" search and rescue association sample. International Journal of Human Sciences, 11(2), 754-769. doi: $\underline{10.14687 / \text { ijhs.v11i2.2853 }}$

Expectations from search and rescue activities do not point to a specific expectation. This finding can also be related to previously mentioned volunteerism and highly developed sense of belonging. Participants focused on items such as "Being healthy and maintaining health" (19\%), "Being a trainer" (24,6\%); "Being an instructor in the field of search and rescue" (28,6\%) and "Being an international search and rescue professional" (25,4\%). Based on these results, it can be claimed that the most prominent expectation from search and rescue activities was to be a trainer in the future. In terms of the total percentage, $53.2 \%$ of the participants stated that they would like to be trainers. Gürer (2012:96) mentioned a hierarchy in the participants who undertake search and rescue activities, in the system structure and in authority and responsibility. Based on this, the importance of being a trainer in the system can be understood better. It is obvious that being a trainer is an important status in the structure of search and rescue activities. Hannestad (2005) also mentioned that management and command are important core components in search and rescue chain. In this sense, trainers may have effective statuses in the voluntary structure. In AKUT where $80.2 \%$ of the volunteers have at least graduate or higher academic education, the active volunteers are equipped with similar levels of knowledge and competences as their leaders throughout their academic experiences.

Various interferences can be made from the results of the study. It is possible to prove that volunteerism is an important factor in AKUT which can also be found in their mission and vision statements. It can also be stated that being a trainer at some point in the process is the most significant expectation for participants.

A significant relationship was found between the age of the participants and their expectations. Young participants were found to have higher expectation's compared to older participants (\% 53,2). Table 6 and table 7 present that these expectations generally centered on being a trainer $(\mathrm{P}<0,05)$.

\section{Conclusions}

Young participants expect to be trainers in AKUT structure. We see a hierarchical structure in voluntary organizations and especially in search and rescue activities which require effort. Expectations to be trainers in the future may be important for feelings of emotional commitment and the continuation and permanence of the order in the structure. Development of emotional 
Gürer, B., \& Kllinç, Z. (2014). Research on preferences for participation in search and rescue activities: "Akut" search and rescue association sample. International Journal of Human Sciences, 11(2), 754-769. doi: $\underline{10.14687 / \text { ijhs.v11i2.2853 }}$

commitment by volunteers shows that they trust the organization and adopt its characteristics (Caymaz, Erenel \& Gürer, 2013:140). Based on these findings, it can be concluded that expectation to be trainers in the future is crucial.

The fact that the current study is limited with the sample of AKUT Search and Rescue Association may negatively affect the generalizability of the findings. Doing similar research in other voluntary organizations and institutions is important to generalize the findings. Despite the limitations of the study, it is believed that the current study will have important contributions to the literature regarding the expectations form participating in search and rescue activities since there are no similar prior studies in Turkey and the study was conducted in an organization with branches in 32 different provinces in Turkey. The leaders are required to motivate the members mentally and increase the level of motivation. An advanced level of individualized consideration of the leader is mentioned as an important fact by the participants. Accordingly, such a leader will provide confidence among the members. A passive management style is not acceptable while an active and motivating leader is recommended.

\section{References}

Adakale, T. (2011). Characteristics of mountain accidents analysis and determination of optimal search and rescue methods: The interdisciplinary techniques. Search and Rescue Symposium in Outdoor, Summary manual, Ankara.

Bayraktar B, Sunay H. (2004). The Factors Affectıng Turkish Elite Men And Women Volleyball Players Starting Sports And Their Expectations. 8. International Sports Science Congress Manual.

Calisi, D. Iocchi, L., Nardi, D., Randelli, G., Ziparo, V.A. (2009). Improving search and rescue using contextual information. Advanced Robotics. 23, 1199-1216.

Caymaz, E., Erenel, F., Gürer, B. (2013). The effect of leadership charisma, engagement and group belonging on volunteer work performance: AKUT Search And Rescue Association example. International Journal of Human Sciences. Vol: (10)1, 129-147.

Collins, L. (2010). U.S. Response to haiti earthquake. California Task Force Rescues. Fire Engineering, 51.

Gülkan, P. Balamir, M., Yakut, A. (2003). Strategic principles of disaster management: General overwiev of politics in Turkey and World. Middle East Technical University Disaster Management Implementation and Research Center, pp. 30-32.

Gürer, B. (2012). Investigating the leadership skills in outdoor sports \& search and rescue. Abant İzet Baysal University, Unpublished $\mathrm{PhD}$ thesis

Gürer, B., Adiloğulları I., Caymaz, E., (2012). Examining of acute volunteers' levels of organizational commitment in terms of some variables. Selcuk University Journal of Physical Education and Sports Science, Vol: 14 (2): 290-297 
Gürer, B., \& Kllınç, Z. (2014). Research on preferences for participation in search and rescue activities: "Akut" search and rescue association sample. International Journal of Human Sciences, 11(2), 754-769. doi: $\underline{10.14687 / \text { ijhs.v11i2.2853 }}$

Hannestad, S. E. (2005). Incident command system: A developing national standard of incident management in the U.S., Walle B.V. and B. Carle, B. (eds.), Proceedings of the 2nd International ISCRAM Conference, Humanitarian Knowledge Management. 19-28.

IAMSAR, (2008). International aeronautical and maritime search and rescue manual. Search and Rescue. Organisation and Management. 1. 24-57.

McManners, H. (2009). Survival guide (First edition). (Trs. Z.G. Üstün). İstanbul: Kaknüs Publictions.

Ölçücü, B., Erdil, G., Bostanc1, Ö., Canikli, A., Aybek, A., (2012). The reasons of athletes who participate in intercolegiate tennis competitions for taking up tennis and their expectations. Journal of Sports and Performance Researches, 3 (2), 6.

Saeedi, P., Sorensen, S.A. (2009). An algorithmic approach to generate after-disaster test fields for search and rescue agents. Proceedings of the World Congress on Engineering, 1-3 July, London, 978-988), Publisher: Newswood Limited.

Setnicka, J.T. (1980). Wilderness search and recue. K. Andrasko (ed.). Boston: Appalachian Mountain Club

Sunay, H., Saracaloğlu, A.S., (2003). The factors direct to the branches of turkish athletes and their expectations. Ankara University School of Physical Education and Sports, Spormetre Journal of Physical Education and Sports Science, 1(1), 43-48.

Şimsek, D., (2005). Determine The Reasons Of Turkish Students Interested In Athletics Why They Choose This Sport And Their Expectations, Gazi University, Institute of Education Sciences, Department of Physical Education and Sports Teacher, Master Thesis.

Wu, G.J., Chang, Y. (2010). Outdoor risk management training tool: The development of critical adventure scenario exercise (CASE). Proceedings National Conference on Outdoor Leadership 1720.

Yildırım, Y., (2007). The Expectations and Reasons to Begin to Play Tennis for Athletes Who Play Performance Tennis in Turkey, Ankara University School of Physical Education and Sports, Ankara University Institute of Health Sciences, Master Thesis. 